\title{
IPTEK BAGI DESA BERBASIS SISTEM APLIKASI AKUNTANSI MENUJU DESA WIRAUSAHA
}

\author{
Putri Nugrahaningsih ${ }^{1}$, Sri Suranta ${ }^{2}$ \\ ${ }^{1,2)}$ Prodi Akuntansi, Fakultas Ekonomi dan Bisnis, Universitas Sebelas Maret \\ Email: putrinugrahaningsih@staff.uns.ac.id
}

\begin{abstract}
ABSTRAK
Penelitian ini bertujuan untuk mendorong terciptanya aparatur pemerintahan desa yang mampu, terampil, dan profesional dalam pengelolaan Dana Desa, sehingga pemanfaatan dana tersebut lebih optimal. Selain Sumber daya Manusia yang handal juga harus dibekali prasarana penunjang Iptek. Metoda penelitian yang digunakan adalah deskriptif kualitatif, dengan teknik pengumpulan data meliputi focus group discussion, in-depth interview, observasi dan dokumentasi di desa Bulusulur, Kabupaten Wonogiri.

Hasil penelitian menemukan bahwa implementasi Dana Desa dilakukan dengan Pembentukan Badan Usaha Milik Desa (BUMDes) yang memiliki empat unit Usaha. Untuk menjawab kebutuhan BUMDes akan akuntabilitas, transparansi, dan informasi, maka diimplementasikan Program aplikasi Sistem Informasi Akuntansi Keuangan BUMDes berbasis website untuk kemudahan penginputan dan pengolahan segala data transaksi keuangan, serta penyusunan pelaporan keuangan BUMDes. Aplikasi ini dikembangkan sebagai dedikasi untuk mendorong terbangunnya keterbukaan informasi publik di Indonesia untuk tata kelola keuangan BUMDes yang makin profesional, akuntabel, dan transparan.
\end{abstract}

Kata kunci: Dana Desa, BUMDes, Sistem Informasi, Desa

\begin{abstract}
This study aims to encourage the development of capable, skilled, and professional village government in managing village funds, so that the funds can be used optimally. Besides reliable human resources, supporting infrastructure in the form of information and communication technology. This study employs descriptive and qualitative method, with group discussion, in-depth interview, observation, and documentation technique to collect the data at Bulusulur Village, Wonogiri District.

The analysis result shows that the village fund is implemented by establishing BUMDes with four business units. To answer BUMDes needs in accountability, transparency, and information, web-based Financial Accounting Information System BUMDes is implemented to facilitate input and analysis of all data regarding financial transaction, as well as preparation of BUMDes financial report. This application is developed as a dedication to encourage openness in public information in Indonesia as well as to develop professional, accountable, and transparent BUMDes financial management.
\end{abstract}

Keywords: Village Fund, BUMDes, Information System, Village 


\section{PENDAHULUAN}

UU Nomor 6 Tahun 2014 tentang Desa menjadi prioritas penting bagi Pemerintahan Jokowi-Jusuf Kalla, yang mana Desa diposisikan sebagai "kekuatan besar" yang akan memberikan kontribusi terhadap misi Indonesia yang berdaulat, sejahtera dan bermartabat. Dalam NAWACITA, khususnya Nawacita ke-tiga "Membangun Indonesia dari Pinggiran dengan Memperkuat Daerah-daerah dan Desa dalam Kerangka Negara Kesatuan", Pemerintahan Jokowi-JK berkomitmen mengawal implementasi UU Desa secara sistematis, konsisten dan berkelanjutan, untuk mencapai Desa yang maju, kuat, mandiri dan demokratis (Putra, 2015).

Momentum diluncurkannya Undang-undang Nomor 6 Tahun 2014 tentang Desa dan yang kemudian diikuti dengan Peraturan Menteri Desa Pembangunan Daerah Tertinggal dan Transmigrasi Nomor 4 Tahun 2015 tentang Pendirian, Pengurusan Pengelolaan dan Pembubaran Badan Usaha Milik telah mendorong desa untuk mengelola sumber daya yang ada di desa, termasuk pengembangan ekonomi masyarakatnya. Salah satu cara untuk mengelola ekonomi masyarakat desa itu adalah dengan dibentuknya Badan Usaha Milik Desa (BUMDes). UU Nomor 6 Tahun 2014 mengangkat desa menjadi subjek kepemerintahan, yaitu dari sekedar objek pembangunan sekarang menjadi subjek pembangunan (Hoesada, 2014).

Menurut Deputi Pengawasan Bidang Penyelenggaraan Keuangan Daerah bahwa dalam pemberian dana ke desa yang begitu besar, jumlah pelaporan yang beragam serta adanya titik-titik kritis dalam pengelolaan keuangan desa tentunya menuntut tanggung jawab yang besar pula oleh Aparat Pemerintah Desa. Oleh karena itu Pemerintah Desa harus bisa menerapkan prinsip akuntabilitas dalam pengelolaan keuangan desa, yang mana semua akhir kegiatan penyelenggaraan pemerintahan desa harus dapat dipertanggungjawabkan kepada masyarakat desa sesuai dengan ketentuan sehingga terwujud tata kelola pemerintahan desa yang baik (Good Village Governance) (Juklakbimkondesa, 2015).

Untuk dapat menerapkan prinsip akuntabilitas tersebut, diperlukan berbagai sumber daya dan sarana pendukung, diantaranya sumber daya manusia yang kompeten serta dukungan sarana teknologi informasi yang memadai dan dapat diandalkan. Namun demikan, dilihat dari kondisi SDM Desa yang belum memadai, banyak pihak mengkhawatirkan dalam pelaksanaan UU Desa ini. Terdapat risiko-risiko yang yang harus diantisipasi agar tidak terjadi apa yang dikhawatirkan tersebut. 
Menurut Deputi Bidang Akuntan Negara (BAN) BPKP, agar BUMDes dapat dikelola dengan profesional, transparan, dan akuntable, diperlukan aplikasi terkomputerisasi untuk pengelolaan keuangan BUMDesa. Aplikasi Keuangan BUMDES, adalah aplikasi yang dikembangkan untuk membantu proses pengelolaan keuangan dan manajemen administrasi BUMDES dikelola secara professional melalui sebuah sistem informasi berbasis website, atau yang lebih dikenal dengan sebutan program aplikasi. BUMDes pada umumnya menghadapi kendala dalam mengakses, mengembangkan, dan mengolah informasi. Keterbatasan informasi berdampak pada lemahnya efektivitas dan efisiensi pengelolaan BUMDes. Selain itu, bagi para pemangku kepentingan keterbatasan atau asimetri informasi menyebabkan rendahnya transparansi dan akuntabilitas BUMDes.

Penelitian sebelumnya, Ismail (2016), hasil penelitian menunjukkan bahwa penerapan program sistem akuntansi pengelolaan dana desa yang terkomputerisasi dapat mengatasi permasalahan terkait pengelolaan dana desa. Sistem komputerisai ini akan memberi kemudahan kepada aparat desa mulai dari perencanaan, pencatatan secara akuntansi sampai membuat laporan keuangan semesteran dan tahunan.

Oleh sebab itu, Penelitian ini bertujuan untuk memfasilitasi pihak pengelola Dana Desa terutama dalam pengelolaan BUMDes dan pertanggungjawaban pelaporan keuangan dengan penggunaan teknologi dan sistem informasi sehingga dapat memangkas biaya transaksi dan memungkinkan BUMDes mengakses informasi tentang pasar secara lebih efektif. Program aplikasi yang akan diimplementasikan melalui Pelatihan dan Bimbingan Teknis pada BUMDes Desa Bulusulur yaitu Sistem Informasi Akuntansi Keuangan BUMDes (SIKABUMDES).

SIKABUMDES VERSI 7.05 merupakan aplikasi Sistem Informasi Akuntansi Keuangan BUMDes Ver 7.05 yang dibangun berbasis web dengan bahasa pemograman PHP serta menggunakan database MySQL, sehingga menjadikan aplikasi ini ringan dan dapat dengan mudah diinstalasi dan digunakan. Aplikasi ini juga mampu dijalankan melalui jaringan intranet maupun jaringan berbasis client server serta jaringan berbasis online internet. Aplikasi ini dikembangkan sebagai dedikasi untuk mendorong terbangunnya keterbukaan informasi publik di Indonesia terkhusus lagi bagi Badan Usaha Milik Desa (www.softwaredesa.com). Aplikasi ini dibangun dengan prinsip kemudahan (user friendly) dan fitur-fitur yang ada di dalam sistem dibuat sederhana untuk menyikapi kondisi desa yang bervariasi dan memudahkan implementasinya. Program aplikasi ini memberikan kemudahan dalam penginputan dan pengolahan segala data transaksi 
keuangan BUMDes, baik transaksi Uang Kas Masuk maupun Uang Kas Keluar. Dengan satu kali proses penginputan sesuai dengan transaksi yang ada, sistem aplikasi ini dapat menghasilkan output berupa dokumen penatausahaan dan laporan-laporan yang sesuai dengan ketentuan perundang-undangan.

\section{METODE}

Badan Usaha Milik Desa (BUMDes) harus melaksanakan pencatatan dan pembukuan yang sistematis dari transaksi yang terjadi setiap hari (kronologis). Pencatatan transaksi itu umumnya menggunakan sistem akuntansi. Fungsi dari akuntansi adalah untuk menyajikan informasi keuangan kepada pihak internal dan eksternal dan sebagai dasar membuat keputusan. Pihak internal BUMDes adalah pengelola dan Dewan Komisaris, sedangkan pihak eksternal adalah Pemerintah Kabupaten, Perbankan, masyarakat yang memberikan penyertaan modal, dan petugas pajak.

Metode penelitian ini merupakan penelitian kualitatif deskriptif dengan pendekatan penelitian studi kasus. Lokasi penelitian adalah Desa Bulusulur Kecamatan Wonogiri, Kabupaten Wonogiri. Instrumen pengumpulan data dilakukan melalui teknik focus group discussion, wawancara secara mendalam (in-depth interview), observasi, dan dokumentasi. Metode tersebut dilakukan dengan membandingkan antara hasil wawancara dengan hasil observasi dan antara hasil wawancara dengan dokumentasi yang diperoleh.

Pemilihan lokasi pada desa Bulusulur dengan pertimbangan bahwa wilayah desa ini telah memperoleh pencairan dana desa dan programnya sudah dalam tahap pelaksanaan dan rencana pengembangan. Penelitian ini melakukan observasi dengan peninjauan langsung pada desa untuk mendapatkan gambaran nyata mengenai kesiapan penatausahaan dan pengelolaan keuangan BUMDes yang sedang berjalan untuk memperoleh gambaran tentang kesiapan dan proses serta format pelaporan dana desa. Wawancara dilakukan dengan cara bertanya langsung dengan narasumber mulai dari kepala desa, bendahara, Direktur BUMDes, badan perwakilan desa serta masyarakat terkait pengelolaan dana desa termasuk juga pelaporannya.

Sumber data yang digunakan dalam penelitian ini adalah 1) sumber data primer: data yang diperoleh melalui informan dengan cara melakukan tanya jawab secara langsung dan dipandu dengan pedoman wawancara terstruktur yang sesuai dengan fokus penelitian, yakni Kepala Desa Bulusulur, beserta perangkatnya, Direktur BUMDes, Unit Pengelola kelompok UKM, Fasilitator Desa, Aparat pengawas Kecamatan dan Kabupaten; dan 2) 
Sumber data sekunder: data yang diperoleh melalui beberapa informasi antara lain dokumen (meliputi profil desa Bulusulur, peraturan-peraturan terkait desa), Petunjuk Pelaksanaan Implementasi dan Manual Program Aplikasi SIKABUMDES, buku teori (ilmiah), dan hasil penelitian (artikel dan jurnal).

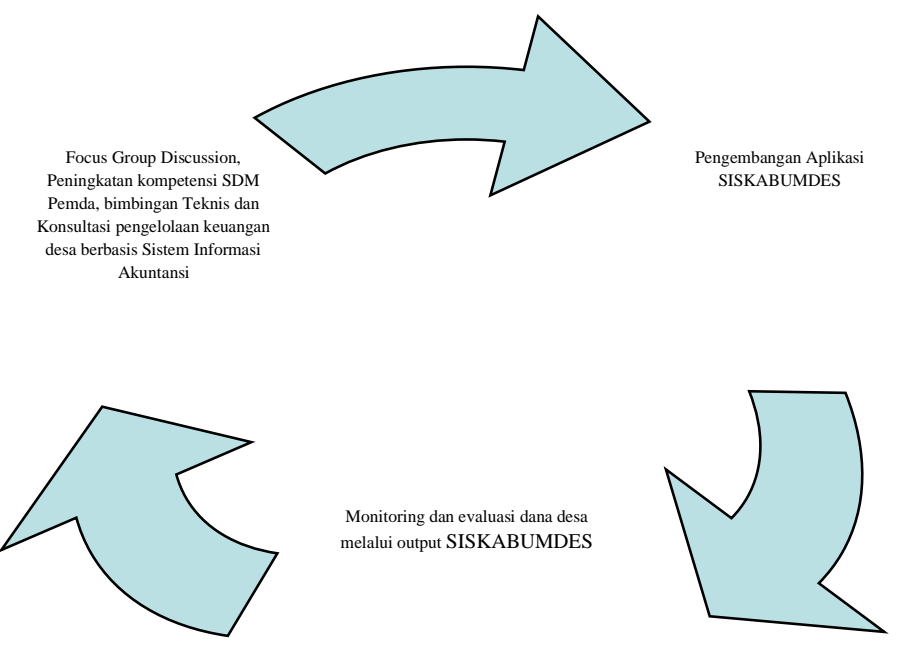

Figure 3.1

Program Aplikasi Sistem Informasi Akuntansi BUMDes

\section{HASIL DAN PEMBAHASAN}

\section{Focus Group Discussion Badan Usaha Milik Desa di Desa Bulusulur}

Badan Usaha Milik Desa (BUMDes) adalah badan usaha yang ada di desa yang di bentuk oleh pemerintahan desa bersama masyarakat desa melalui musyawarah desa. Untuk memperkuat tatakelola keuangan BUMDes yang makin Transparan, Tim peneliti telah mempersiapkan aplikasi SIA BUMDes yang dirancang sesuai kebutuhan desa (www.softwaredesa.com).

Salah satu cara untuk mengelola ekonomi masyarakat desa itu adalah dengan dibentuk Badan Usaha Milik Desa (BUMDes). Berdasarkan hasil in-depth interview dan observasi, bahwa implementasi dana desa dengan dibentuknya Badan Usaha Milik Desa (BUMDes) yang memiliki empat (4) unit Usaha, yaitu 1) Kolam Keceh dan Bumi Perkemahan, 2) Sarana Air Bersih, 3) Bank Sampah, dan 4) Kerajinan. Kelima Unit Usaha tersebut dipimpin dan dikoordinasikan oleh seorang Direktur BUMDes yaitu Bp. Anggoro.

Pembentukan BUMDes yang ada di desa Bulusulur ini sudah sesuai dengan peraturan desa yang ada dimulai dari dasar hukum yang melandasi, anggaran dasar 
maupun anggaran rumah tangga yang tersusun, dan struktur organisasinya. Mekanisme penyaluran dan pemanfaatan dana ke BUMDes sudah jelas, bahwa dana awal yang dimiliki oleh bumdes ini berasal dari dana hibah yang diberikan oleh pemerintah desa ke badan usaha milik desa. yang ingin memberikan pinjaman modal.

Dalam rangka untuk meningkatkan pengawasan keuangan desa maka diselenggarakan bimbingan teknis dan Focus Group Discussion (FGD) serta monitoring. Khalayak sasaran yang diundang pada pelatihan ini adalah Kepala Desa, beserta perangkatnya, Direktur BUMDes, Unit Pengelola kelompok UKM, Fasilitator Desa, Aparat pengawas Kecamatan dan Kabupaten. Pelaksanaan program penelitian ini akan dilakukan melalui beberapa tahapan. Tahapan tersebut adalah 1) Pemaparan dan diskusi melalui focus group discussion dengan stakeholder terkait dengan pengumpulan informasi mengenai keadaan existing profil 2) melakukan koordinasi baik meliputi Pemerintah Desa dan BPD, serta masyarakat dalam proses perencanaan, pelaksanaan, pemanfaatan, dan pemeliharaan hasil-hasil pembangunan dana desa; 3) melakukan bimbingan teknis dan Konsultasi (Bimkon) Pengelolaan Keuangan Desa dengan berbasis Aplikasi Sistem Informasi Akuntansi Keuangan BUMDes. Berikut dokumentasi kegiatan pendampingan di Bulusulur.

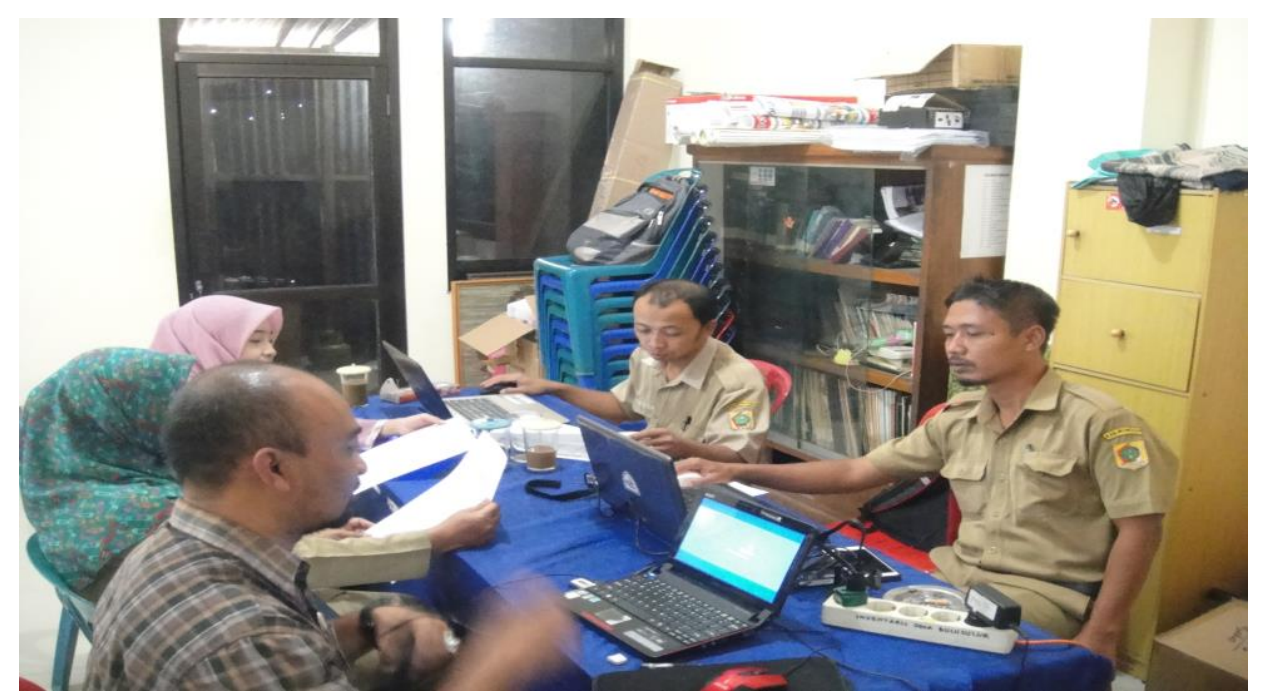

Gambar 1. Koordinasi dan FGD dengan pengelola BUMDes

Pelatihan Industri Kerajinan Rumah Tangga Dengan Pemanfaatan Bank Sampah Dalam Rangka Peningkatan Peran Aktif Bumdes Wahana Artha Nugraha Desa Bulusulur, Kecamatan Wonogiri Menuju Desa Wisata

Pengabdian Pada Masyarakat ini bertujuan untuk memberikan pengetahuan dan pelatihan kepada ibu-ibu dan remaja putus sekolah dalam bentuk ceramah dan 
pemberian keterampilan tentang pemanfaatan limbah kemasan plastik menjadi produk seni kerajinan yang memiliki nilai ekonomis yang nantinya dapat meningkatkan pengasilan keluarga. Tujuan dalam pengelolaan sampah berupa limbah kemasan plastik adalah sebagai berikut :

1. menjadikan sampah bernilai ekonomis melalui proses daur ulang, pembuatan biogas dan kompos, serta pembuatan pakan ternak.

2. dapat memberikan nilai efisiensi terhadap biaya operasional

3. mempunyai nilai tambah

4. dapat membuka peluang kesempatan bekerja, dan

5. memperpanjang tempat penambungan akhir (TPA)

Beberapa dari bahan ini seperti plastik dan alumunium dan sebagian besar bahan anorganik secara keseluruhan tidak dapat diuraikan oleh alam. Sampah jenis ini pada tingkat rumah tangga adalah berupa botol gelas, botol plastik, macam-macam plastik kemasan, dan kaleng.

Sampah anorganik tidak semua dapat didaur ulang dan tidak dapat dihancurkan, untuk itu diperlukan penanganan limbah kemasan plastik dengan cara memanfaatkannya menjadi suatu produk seni kerajinan seperti tudung saji, table mats, celemek plastik, sandal plastik dan lain-lain.

Kegiatan pelatihan ini menggunakan metode ceramah, demonstrasi, tanya jawab dan praktik langsung tentang pemanfaatan limbah kemasan plastik menjadi produk seni kerajinan seperti tas, table mats, tudung saji, wadah minuman, tempat pensil, vas bunga, dan lain-lain. Untuk mengetahui tingkat keberhasilan pelaksanaan pelatihan dilakukan evaluasi tingkat penguasaan keterampilan mulai dari tahap persiapan, pemilihan bahan, mendesain dan pelaksanaan keterampilan membuat produk seni kerajinan dari bahan limbah kemasan plastik.

Hasil pelatihan menunjukkan tingkat keberhasilan yang dicapai tergolong baik, yaitu peserta mampu membuat keterampilan produk seni kerajinan dari bahan limbah kemasan plastik berupa tas, table mats, tudung saji, wadah minuman, tempat pensil, vas bunga, dan lain-lain, dengan baik dan benar. 


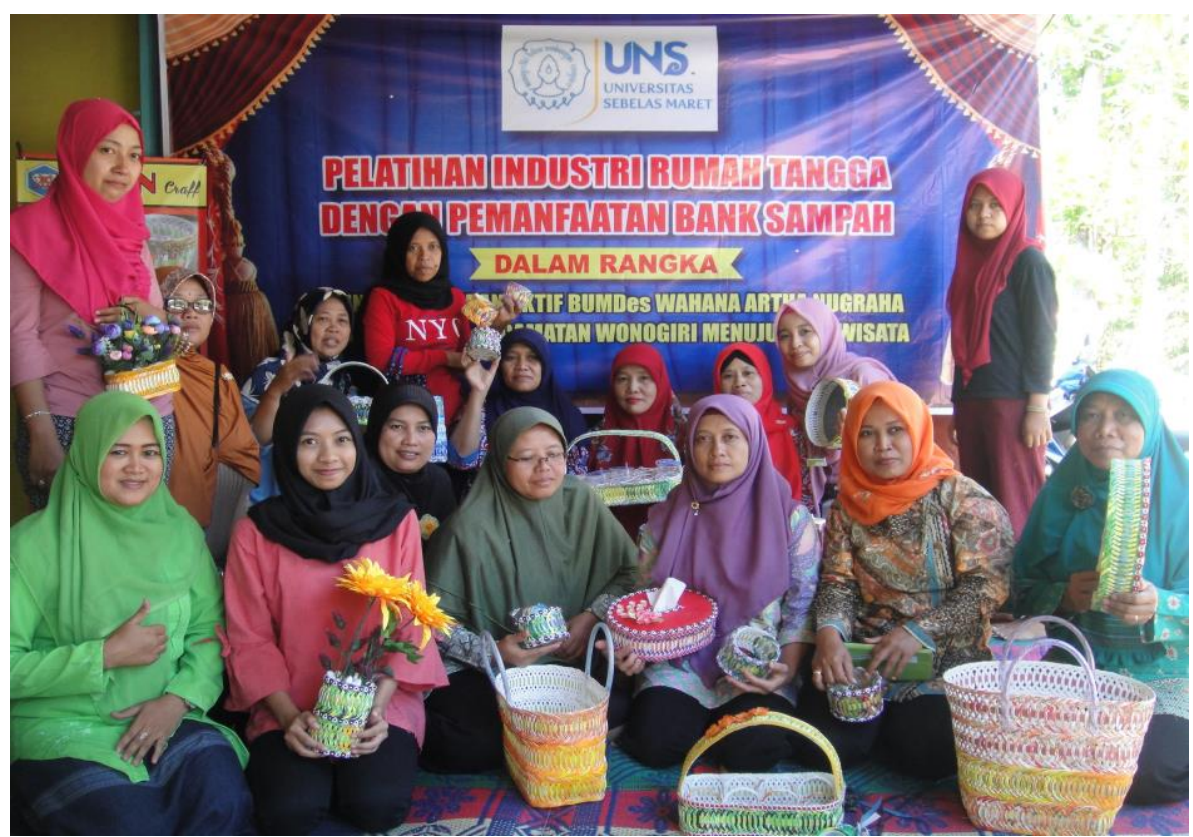

Gambar 2. Pelatihan Industri Rumah Tangga dengan Ibu-Ibu pengelola unit Bank Sampah

\section{Pengelolaan Dana Desa berbasis Sistem Informasi Akuntansi Keuangan BUMDes}

BUMDes harus melakukan pencatatan atau pembukuan yang ditulis secara sistematis dari transaksi yang terjadi setiap hari. Pencatatan transaksi itu umumnya menggunakan sistem akuntansi (Putra, 2015). Fungsi dari akuntansi adalah untuk menyajikan informasi keuangan kepada pihak internal dan eksternal dan sebagai dasar membuat keputusan. Pihak internal BUMDes adalah pengelola dan Dewan Komisaris, sedangkan pihak eksternal adalah Pemerintah Kabupaten, Perbankan, masyarakat yang memberikan penyertaan modal, dan petugas pajak. Secara umum tujuan dilakukannya pembukuan adalah:

1. Untuk mengetahui perkembangan perusahaan dari waktu ke waktu, baik perkembangan omzet penjualan, laba/rugi maupun struktur permodalan.

2. Untuk mengetahui kemungkinan kerugian sejak dini, sehingga gulung tikar bisa dihindari.

3. Untuk mengetahui kondisi persediaan barang/jasa setiap saat. Sehingga dapat digunakan untuk menyusun strategi manajemen persediaan. Pada unit usaha dagang yang disebut persediaan adalah barang dagangan. Pada unit usaha industri adalah persediaan bahan mentah, barang dalam proses maupun barang jadi, Sedang pada unit simpan pinjam adalah persediaan uang. 
4. Untuk mengetahui sumber dan penggunaan dana BUMDes, sehingga bisa mengevaluasi kinerja keuangan BUMDes seperti likuiditas, solvabilitas maupun rentabilitasperusahaan.

SIKABUMDES VER 7.08 merupakan aplikasi Sistem Informasi Akuntansi Keuangan BUMDes Ver 7.08 yang dibangun berbasis web dengan bahasa pemograman PHP serta menggunakan database MySQL, sehingga menjadikan aplikasi ini ringan dan dapat dengan mudah diinstalasi dan digunakan. Aplikasi ini juga mampu dijalankan melalui jaringan intranet maupun jaringan berbasis client server serta jaringan berbasis online internet. Aplikasi ini dikembangkan sebagai dedikasi untuk mendorong terbangunnya keterbukaan informasi publik di Indonesia terkhusus lagi bagi Badan Usaha Milik Desa (BUMDes).

Dibangun dengan prinsip kemudahan (user friendly), sistem aplikasi ini memberikan kemudahan dalam penginputan dan pengolahan segala data transaksi keuangan BUMDes, baik transaksi Uang Kas Masuk maupun Uang Kas Keluar. Fitur SIKABUMDES meliputi (1) Parameter Informasi Tentang BUMDes; (2) Parameter List Akun; (3) Pencatatan Transaksi Uang Masuk; (4) Pencatatan Transaksi Uang Keluar; (5) Akuntansi Posting Buku Kas; (6) Akuntansi Input Jurnal Umum Manual; (7) Laporan Laba Rugi; (8) Neraca BUMDes; dan (9) mampu terintegrasi Online. Beberapa hasil screenshoot pengolahan data transaksi dapat dilihat pada gambar berikut.

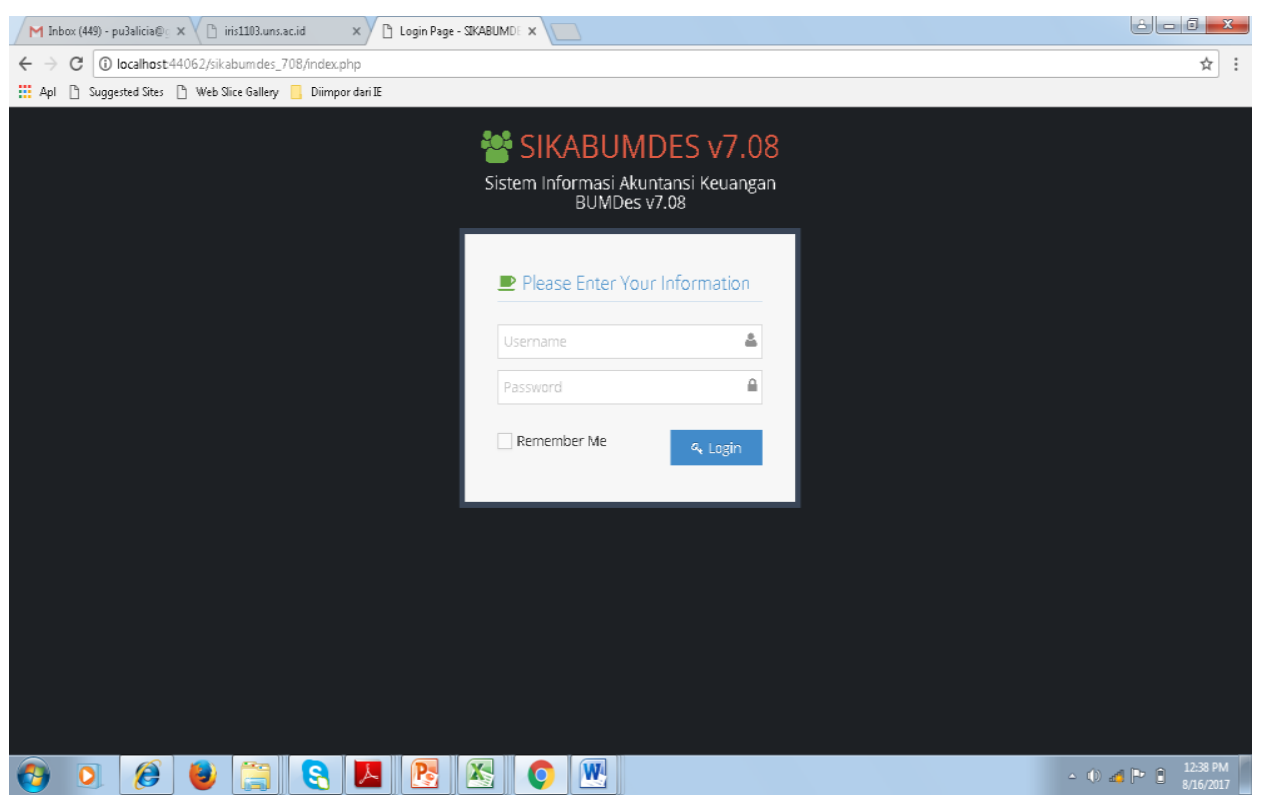

Gambar 3. Halaman Login 


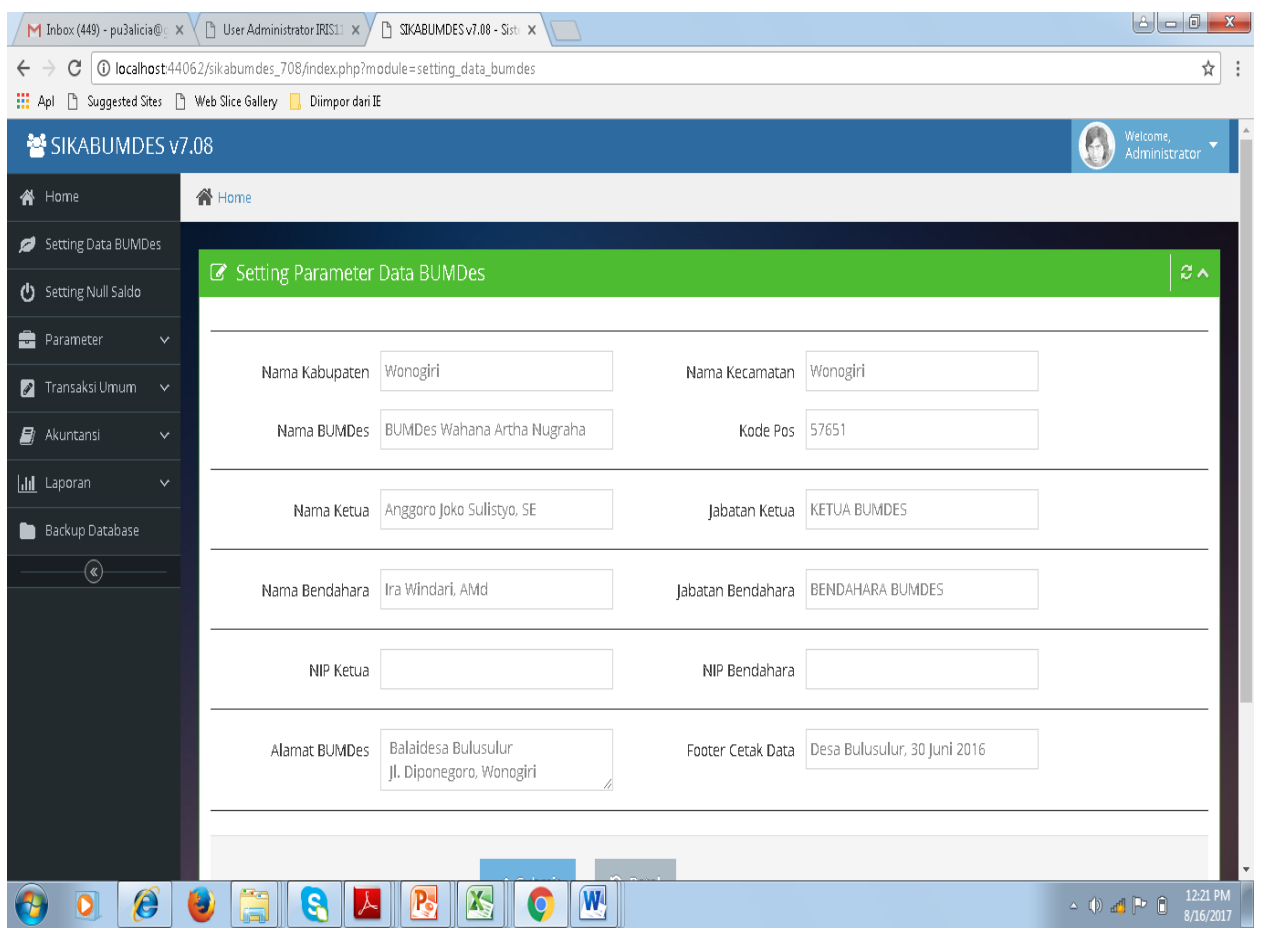

Gambar 4. Halaman Parameter Identitas tentang BUMDes

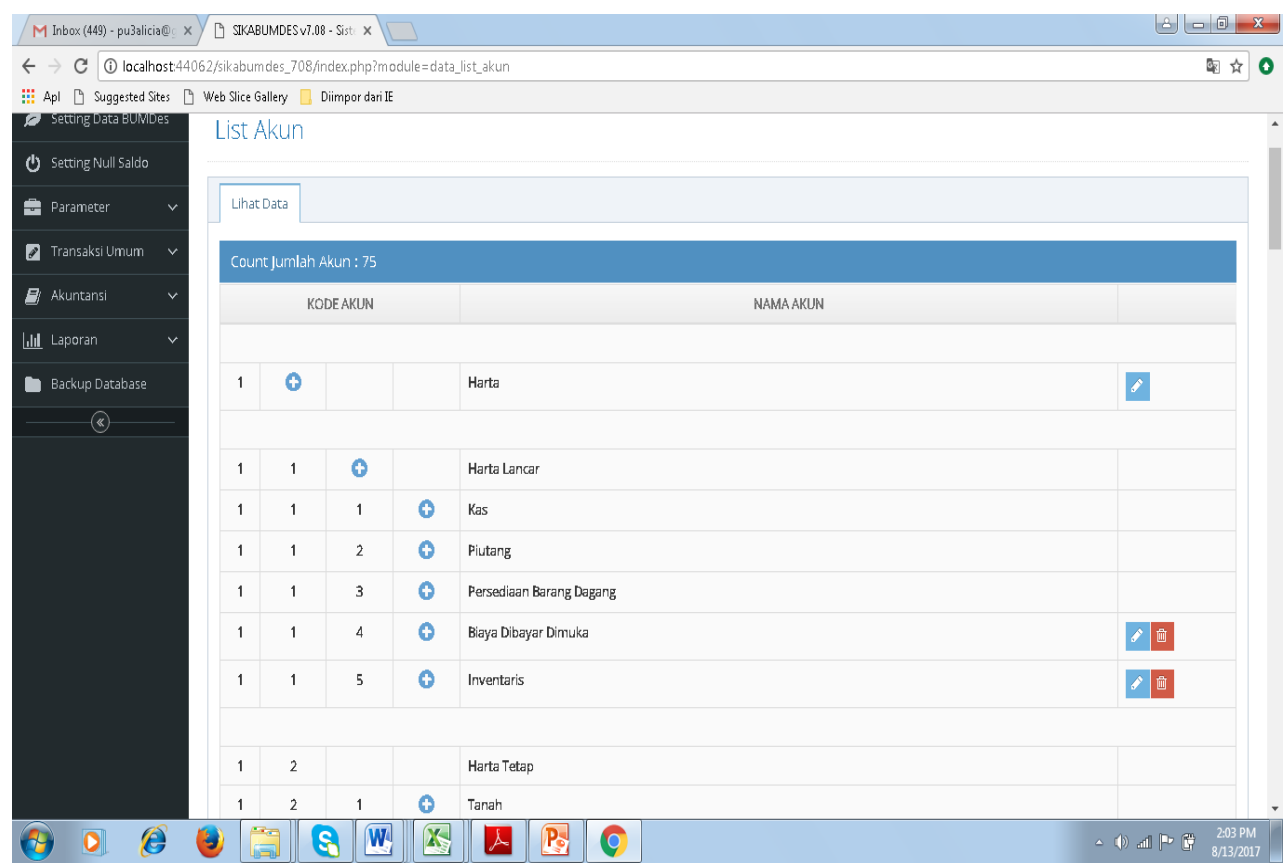

Gambar 5. Parameter List Akun 


\section{PENUTUP}

1. Implikasi dari penelitian ini adalah bahwa penerapan iptek dalam pengelolaan dana desa dengan sistem informasi akuntansi BUMDes yang berbasis website dapat mengatasi permasalahan terkait pengelolaan dana desa. Program aplikasi telah memberi kemudahan kepada unit pengelola dan aparat desa mulai dari perencanaan, pencatatan secara akuntansi sampai membuat laporan keuangan semesteran dan tahunan. Hal ini mendorong tata kelola keuangan desa yang baik; perencanaan Desa yang partisipatif, tercipta akuntabilitas publik dan transparansi, terintegrasi dan selaras dengan perencanaan daerah dan nasional; Berkurangnya penyalahgunaan kekuasaan dan kewenangan yang mengakibatkan permasalahan hukum; serta Mutu pelayanan kepada masyarakat meningkat.

2. Keunggulan \& Fitur Sistem Informasi Akuntansi Keuangan BUMDes

Keunggulan Sistem Informasi Akuntansi Keuangan BUMDes (SIKABUMDES) mencakup :

a. Dengan menggunakan SIKABUMDES, maka pengguna sistem aplikasi tidak perlu melakukan penjurnalan manual, karena oleh SIKABUMDES telah dilakukan penjurnalan secara otomatis

b. Dengan menggunakan SIKABUMDES, maka pengguna sistem aplikasi dapat melihat secara update otomatis Laporan Laba Rugi berdasarkan periode yang dipilih dan itu dilakukan oleh SIKABUMDES secara otomatisasi ketika transaksi kita masukkan melalui SIKABUMDES tanpa melakukan proses penjurnalan manual

c. Dengan menggunakan SIKABUMDES, maka pengguna sistem aplikasi dapat melihat secara update otomatis Laporan Neraca BUMDes tanpa melakukan proses penjurnalan manual

d. Dengan menggunakan SIKABUMDES, maka pengguna sistem aplikasi dapat melakukan pemeliharaan pada masing - masing Akun Kode Rekening

e. Dengan menggunakan SIKABUMDES, maka pengguna sistem aplikasi dapat melakukan pembukuan transaksi melalui Transaksi Arus Kas Masuk dan Arus Kas Keluar. 


\section{UCAPAN TERIMA KASIH}

Kegiatan Iptek bagi Desa Mitra (IbDM) ini terselenggara atas pembiayaan dari PNBP Universitas Sebelas Maret Tahun Anggaran 2017 sesuai dengan Perjanjian Pelaksanaan Pengabdian Kepada Masyarakat Nomor: 624/UN27.21/PM/2017, tanggal 10 April 2017 dan Lembaga Penelitian \& Pengabdian Kepada Masyarakat UNS atas segala dukungan

\section{REFERENSI}

Badan Pembinaan Pengelolaan Keuangan Pemerintahan Daerah. 2016. Proposal Pembuatan Sistem Informasi Keuangan Aplikasi Pengelolaan BUMDES (Badan Usaha Milik Desa). Available at http://www.bppkpd.com.

Badan Pengawas Keuangan dan Pembangunan. 2016. BPKP Luncurkan SIA BUM Desa Sekaligus Perkuat Kapasitas BUMD. Available at http://www.bpkp.go.id.

Departemen Pendidikan Nasional. 2007. Buku Panduan Pendirian dan Pengelolaan BUMDes. PKDSP: FE Universitas Brawijaya.

Desa, Blogger. 2017. SIA BUM Desa: Sistem Informasi Akuntansi Badan Usaha Milik Desa. Available at http://www.risehtunong.blogspot.co.id.

Halim, Abdul. Akuntansi Keuangan Daerah. 2008. Jakarta: Salemba Empat

Hoesada, J. 2014. Komite Standar Akuntansi Pemerintah (KSAP). Jakarta.

Ismail, Muhammad., Ari Kuncoro W dan Agus W. 2016. Sistem Akuntansi Pengelolaan Dana Desa. Jurnal Ekonomi dan Bisnis. Vol.XIX No.2:323-340.

Kurnia, Dadang. 2015. Pengawalan Akuntabilitas Pengelolaan Keuangan Desa. BPKP. Jakarta.

Mardiasmo. 2009. Akuntansi Sektor Publik. Jakarta: CV Andi Offset.

Peraturan Menteri Dalam Negeri Nomor 113 Tahun 2014 tentang Pengelolaan Keuangan Desa. 
Peraturan Pemerintah Nomor 43 Tahun 2014 tentang Peraturan Pelaksanaan Undang-Undang Nomor 6 Tahun 2014 tentang Desa.

Peraturan Pemerintah Nomor 71 Tahun 2010 tentang Standar Akuntansi Pemerintahan.

Petunjuk Teknis Perencanaan Pembangunan Desa, Lampiran Surat Edaran Menteri Dalam Negeri Nomor 414.2/1408/PMD Tanggal 31 Maret 2010.

Putra, Surya Anom. 2015. Badan Usaha Milik Desa: Spirit Usaha Kolektif Desa. Jakarta: Kementerian Desa, Pembangunan Daerah Tertinggal, dan Transmigrasi RI.

Santri, Premanita. 2015. Akuntabilitas Keuangan Desa: Evaluasi Pengelolaan Alokasi Dana Desa (ADD) di Kabupaten Wonogiri Tahun 2014. Skripsi: Universitas Sebelas Maret.

Sugiyono. 2012 Metode Penelitian Kuantitatif, Kualitatif, dan R\&D. Bandung: Alfabeta.

Taman, Abdullah., dkk. 2015. Pelatihan Penyusunan Laporan Keuangan Dana Desa Bagi Perangkat Desa Di Kecamatan Gamping Sleman. Universitas Negeri Yogjakarta.

Undang-Undang Republik Indonesia Nomor 6 Tahun 2014 tentang Desa.

Undang-Undang Republik Indonesia Nomor 12 Tahun 2008 tentang Pemerintahan Daerah. Jakarta. Direktorat Jenderal Otonomi Daerah.

\section{BIODATA PENELITI}

\section{Putri Nugrahaningsih, SE, M.Ak, Ak., CA}

Tenaga Pendidik atau dosen di program studi Akuntansi Fakultas Ekonomi dan Bisnis Universitas Sebelas Maret. Lulusan S2 Universitas Indonesia Tahun 2013. Dilahirkan di Karanganyar pada 14 Juni 1983. Saat ini menjabat sebagai koordinator Pengabdian pada Masyarakat pada Unit Pengaduan dan Penjaminan Mutu Penelitian dan Pengabdian pada Masyarakat LPPM UNS. Pengalaman Penelitian dan pengabdian pada masyarakat diantaranya IbDM Peningkatan Peran Aktif BUMDes Desa Bulusulur Kecamatan Wonogiri Kabupaten Wonogiri menuju Desa Wisata. 